\title{
Between Cynicism and Idealism: Is the Italian Constitutional Court Passing the Buck to the Italian Judiciary?
}

\author{
Giovanni Boggero and Karin Oellers-Frahm
}

\begin{abstract}
In this chapter we focus on the consequences of Sentenza 238/2014 for the Italian judiciary. The judgment of the Corte Costituzionale obliges the Italian tribunals to admit claims for the reparation of victims or the heirs of victims and to decide on the merits. In this context, a series of difficult legal questions arise that require consistent answers. The practice shows, however, that consistent answers cannot be taken for granted as long as the decision is in the hands of lower-level tribunals. The questions to be solved concern, firstly, who can bring a claim: the victims only or-in cases where they are no longer alive-also their spouses, children, or even grandchildren and other family members? This raises a second question namely whether there is any time limit for bringing claims, which of course touches upon more general concerns, such as intertemporal law, statutory limitations, prescriptions, forfeiture and inadmissibility due to reparation agreements. Thirdly, there is the question as to the specific nature of the reparations: for example, financial reparations and their calculation standards, or satisfaction only? A further question arising from all decisions granting reparation relates to the execution of the judgments, as it seems rather illusory that Germany will comply voluntarily with such judgments. An additional aspect the chapter addresses is the broader impact of the decisions of the Italian judiciary: the non-recognition of state immunity before Italian tribunals will make Italy an attractive forum for similar claims, evidence of which has already emerged. Furthermore, the decisions of the tribunals will servealthough certainly involuntarily_as precedents in similar cases not only in Italy.
\end{abstract}

\footnotetext{
The chapter is the result of a common reflection; nevertheless, sections II and III are attributable to Karin Oellers-Frahm, while sections IV and V to Giovanni Boggero. The introduction (I) and the concluding remarks (VI) were written four hands.
}

G. Boggero $(\square)$

University of Turin, Department of Law, Turin, Italy

e-mail: giovanni.boggero@unito.it

K. Oellers-Frahm

Max Planck Institute for Comparative Public Law and International Law, Heidelberg, Germany

e-mail: oellers.affiliate@mpil.de 
Such effects will concern issues such as (a) the reparation of war-related claims on an individual basis and (b) their consequences for the readiness of states to terminate armed activities by concluding peace treaties and reparation agreements on a lump sum basis. With a view to actual armed conflicts that are mostly not international armed conflicts the question has then to be asked (c) whether individual reparation claims will lead to discriminatory consequences as reparation will probably only be realizable for victims of war crimes committed by state organs and not those committed by non-state actors. The chapter will then conclude by trying to assess more in general the task of constitutional and/or supreme courts to balance the consequences flowing from their decisions against their power or intent to enhance the development of (international) law.

\section{Introduction}

Sentenza $238 / 2014^{1}$ resulted in a grave dilemma for the Italian judiciary, which is expected to comply with the judgment. In particular, cases already pending-or cases that will be brought in the future before a court concerning reparation for war crimes committed by Germany during World War II (WWII) against Italian citizens-will no longer be dismissed on the basis of jurisdictional immunity of Germany. As a matter of principle, ${ }^{2}$ they have to be decided on the merits.

This implies that courts have to decide on a series of complicated issues that have hitherto remained unanswered, such as who may bring a claim, whether there is a time limit for bringing claims and what the specific reparation scheme might look like. A further and highly delicate question relates to the execution of those judgments awarding compensation or reparation. Under general international law states do not only enjoy immunity from adjudication but also immunity from execution ${ }^{3}$ and Sentenza 238/2014 only explicitly denies in the Italian legal order the existence

\footnotetext{
${ }^{1} \mathrm{Cf}$ Karin Oellers-Frahm, 'Das italienische Verfassungsgericht und das Völkerrecht-eine unerfreuliche Beziehung, Anmerkung zur Entscheidung des italienischen Verfassungsgerichts vom 22. Oktober 2014', Europäische Grundrechte-Zeitschrift 42 (2015), 8-16; Stefan Raffeiner, 'Jenseits der Staatenimmunität im deutsch-italienischen Staatenimmunitäten-Fall: Wege und Hürden nach dem Urteil der Corte Costituzionale', Heidelberg Journal of International Law 76 (2016), 451-473; Marco Longobardo, 'The Italian Constitutional Court's Ruling Against State Immunity When International Crimes Occur: Thoughts on Decision No. 238 of 2014', Melbourne Journal of International Law 16 (2015), 255-269; Giuseppe Cataldi, 'La Corte costituzionale e il ricorso ai "contro-limiti" nel rapporto tra consuetudini internazionali e diritti fondamentali', Diritti umani e diritto internazionale 9 (2015), 41-50.

${ }^{2}$ Giovanni Boggero, 'The Legal Implications of Sentenza No. 238/2014 by Italy's Constitutional Court for Italian Municipal Judges: Is Overcoming the 'Triepelian Approach' Possible?', Heidelberg Journal of International Law 76 (2016), 203-224, at 215 et seq, where the author refers to the means available for Italian judges to decide not in conformity with the Constitutional Court's judgment.

${ }^{3}$ Xiaodang Yang, 'Immunity from Execution', in Alexander Orakhelashvili (ed), Research Handbook on Jurisdiction and Immunities in International Law (Cheltenham: Edward Elgar 2016), $372-422$.
} 
of the customary rule of state immunity from adjudication for acta iure imperii involving serious violations of human rights or humanitarian law. At the same time, the 2012 International Court of Justice (ICJ) Judgment remains binding upon Italy under international law, with the consequence that Italian tribunals disregarding that judgment commit a violation of international law that is attributable to the Italian state because the judiciary is an organ acting on behalf of the state (Article 4 of the Draft Articles on State Responsibility); ${ }^{4}$ such violations would occur, in particular, when acts of execution concerning the relevant adjudicatory judgments were adopted.

The following considerations will firstly concentrate on questions to be answered by Italian courts and tribunals and the effect that such decisions may have more generally under international law and, secondly, address the (problems related to) execution. This will lead to a number of reflections concerning potential political solutions, such as reparation agreements between Italy and Germany, and the question of the constitutionality of such solutions.

\section{Attempts by Italian Courts to Cope with the Contrasting Obligations Stemming from International and Domestic Law}

After the delivery of Sentenza 238/2014, the Italian tribunals had to decide on the cases suspended during the proceedings before the ICJ. It was the Tribunal of Florence ${ }^{5}$ - though not the same judge that had referred the question of constitutionality to the Italian Constitutional Court (ItCC) leading to Judgment 238/2014 ${ }^{6}$ that took the first decision following Sentenza. ${ }^{7}$ That decision is clearly characterized by the Tribunal's attempt to find a way between Scylla and Charybdis, namely to comply at the same time with the ICJ Judgment and the Judgment of the ItCC. In its Order of 23 March $2015,{ }^{8}$ the Tribunal explicitly mentioned the risk that the Italian

\footnotetext{
${ }^{4}$ ILC, Draft Articles on Responsibility of States for Internationally Wrongful Acts, adopted by the Commission at its fifty-third session in 2001 (Final Outcome), UN Doc A/56/10, 43, UN Doc A/RES/56/83, Annex, UN Doc A/CN.4/L.602/Rev.1, GAOR 56 ${ }^{\text {th }}$ Session Supp 10, 43.

5'Tribunal' is used as translation for 'Tribunale', which generally is a court of first instance in the Italian civil judiciary system. A 'Corte d'Appello' generally reviews the judgment made by the courts of first instance.

${ }^{6}$ It was the Tribunal of Florence that in 2014 referred three questions to the Constitutional Court, leading to Sentenza 238/2014: (1) whether the rule of jurisdictional state immunity applies also in cases of grave human rights violations; (2) whether the law ratifying the UN Charter is constitutional with regard to Art 94 of the Charter concerning the obligation to comply with decisions of the ICJ; and (3) whether the Italian Law No 5 of 14 January 2013 concerning the implementation of the 2012 ICJ Judgment was constitutional.

${ }^{7}$ Corte Costituzionale, Judgment of 22 October 2014, No 238/2014.

${ }^{8}$ Tribunale di Firenze, Order of 23 March 2015, No 2012/1300, where not the victim himself but family members of the victim had brought the claim. Cf Karin Oellers-Frahm, 'A Never-Ending Story: The International Court of Justice-The Italian Constitutional Court-Italian Tribunals and
} 
state would violate international law if it were to disregard the customary rule on state immunity, and the Tribunal thus attempted to find a subtler solution. This solution was linked to paragraph 104 of the ICJ Judgment in which the Court mentioned the advantage, or rather desirability, of renegotiations between Italy and Germany. ${ }^{9}$ On the basis of this approach the Tribunal found that in the case at stake it should proceed by seeking a conciliatory solution. However, as paragraph 104 of the ICJ Judgment could not serve as a legal basis for imposing conciliation, the Tribunal found that "considering that the dispute at hand implies the risk for Italy of committing an international wrongful act (...), an attempt of conciliation between the applicants and the Federal Republic of Germany but also between Italy and Germany (...) should be made in accordance with Article 185 of the Code of Civil Procedure'. ${ }^{10}$ At the same time, the Tribunal itself presented a concrete proposal of conciliation. This proposal provided that Germany grants financial support amounting to $€ 15,000$ to the family members of the victims to enable them to temporarily live in Germany for educational or other cultural purposes and that the plaintiffs in return withdraw their claim. Failing the adoption of this conciliation proposal, formal mediation before a special body would occur. ${ }^{11}$ This approach was followed by the Tribunal of Piacenza in its sentenza non definitiva ("non-final judgment') of 25 September $2015,{ }^{12}$ which was somewhat more cautious as it did not itself present a proposal for conciliation but only 'invited' Italy and Germany to consider the opportunity of depositing a note containing a proposal for an amicable solution. The Tribunal mentioned, however, that the attitude of the parties would be a decisive factor in the regulation of the costs of the procedure-thus trying to put some pressure on the parties to follow the 'invitation' for conciliation. The conciliation solution would in fact have presented an elegant way out of the dilemma with

the Question of Immunity', Heidelberg Journal of International Law 76 (2016), 193-202; Boggero, 'Legal Implications of Sentenza No. 238' 2016 (n 2).

${ }^{9} \mathrm{ICJ}$, Jurisdictional Immunities of the State (Germany v Italy: Greece Intervening), Judgment of 3 February 2012, ICJ Reports 2012, 99, para 104, where the ICJ stated 'the claims arising from the treatment of the Italian military internees (...) together with other claims of Italian nationals which have allegedly not been settled - and which formed the basis for the Italian proceedings—could be the subject of further negotiations involving the two States concerned, with a view to resolving this issue.'

${ }^{10}$ Tribunale di Firenze, Order No 2012/1300 (n 8), 2-3, (translated by the authors).

${ }^{11}$ Ibid, 3.

${ }^{12}$ Tribunale di Piacenza, Decision of 28 September 2015, No 1462/2015. See also, however, Tribunale di Sulmona, Order of 2 November 2017, No 20/2015, 8. Here judge Giovanna Bilò states that 'five years after the judgment of the Court of The Hague the existence of such a far reaching customary law (eg immunity from jurisdiction without any exception) in the international legal order may be doubted' (translated by the authors). Cf in this context, Giovanni Boggero, 'Ancora sul seguito della sentenza n. 238/2014: una recente pronuncia del Tribunale di Sulmona', (20 November 2017), available at www.diritticomparati.it/ancora-sul-seguito-della-sentenza-n2382014-una-recente-pronuncia-del-tribunale-di-sulmona/ and also: Maria Irene Papa/Alessandra Zanobetti, 'Eccidio di Roccaraso: giurisdizione italiana e immunità degli Stati dalla giurisdizione civile', in Il Corriere giuridico 6 (2018), 788-798. 
which the Italian tribunals were confronted, namely that of disregarding neither the decision of the ItCC nor international law as stated by the ICJ. But this attempt failed for two reasons: first, Article 185 of the Italian Code of Civil Procedure was not the proper legal basis, as it provides for negotiations between the plaintiff and the defendant - that is, the individual claimant and Germany - and not between the defendant and a third party - that is, Germany and Italy. ${ }^{13}$ Secondly, Germany unsurprisingly did not react to the decision.

\section{Issues to Be Decided by the Italian Courts}

\section{Who Can Bring a Claim and Who Is a Victim?}

The first question that had to be answered following the failure to find a conciliatory solution concerned the issue of who can bring a claim. The war crimes committed against Italian nationals that represent the origin of the claims were committed by Germany between 1943 and 1945, a time frame that already indicated that a large number of the directly affected persons would not be in a situation to bring their claims personally. Thus, the question arose as to who could bring a claim besides the victims themselves: whether family members, spouses, children, grandchildren or even nieces, nephews and cousins were entitled to claim compensation for the suffering inflicted upon them due to the loss of the family member. As already mentioned, the Italian tribunals did not address this topic at all in a first approach following Sentenza 238/2014, but admitted without further discussion claims brought by any family member and tried to circumvent a decision on the merits by referring the parties to conciliation. ${ }^{14}$ When this attempt failed, the Italian tribunals were bound to decide on the merits, namely to award or decline compensation, and in this context they had to define in more detail who is entitled to bring a claim and receive compensation.

Today there is no question that direct victims are entitled to bring a claim. However, most of the cases were brought by family members as the victims themselves were no longer alive. And as the practice of the Italian courts was unanimous in finding that claims cannot lead to reparation of material damages but only to compensation of immaterial (moral) damages, even where victims themselves brought a case ${ }^{15}$ the way was open to admitting claims from secondary or indirect victims. Such damage resulting from family links/family solidarity was

\footnotetext{
${ }^{13}$ Oellers-Frahm, ‘A Never-Ending Story’ 2016 (n 8), 198.

${ }^{14}$ See section II.

${ }^{15}$ Corte di Cassazione, Judgment of 9 May 2011, No 10107/2011.
} 
defined as danno parentale, and could in principle be claimed whenever a family link existed with regard to the victim. ${ }^{16}$ This very general definition of the danno parentale seemed to give leeway for claims brought by any family member without any further requirement. In 2017, however, it was again the Tribunal of Ascoli Piceno, although in a different but similar case decided on by a different judge than the one that delivered the Order of 8 March 2016, ${ }^{17}$ examining in more detail the issue of who is entitled to compensation for danno parentale. Following the Order of 8 March 2016 it was confirmed in general terms that the danno parentale is, in principle, not submitted to prefixed limits, but that having a family link in itself is an insufficient justification for a claim to compensation. Rather, it is incumbent on the claimants to prove that the loss of the family member had a relevant impact on them personally. In the case before it, the Tribunal of Ascoli Piceno found that neither the brothers nor a nephew of the victim could prove any personal damage and thus dismissed their compensation claim. As other aspects had been dismissed as inadmissible by the Italian tribunals (such as a statutory limitation, forfeiture or limiting claims for compensation), ${ }^{18}$ the requirement of proving substantive personal damage constitutes a necessary and welcome limitation for future claims. This also means, however, that the tribunals will have to investigate the claimants family life and personal relationships dating back, potentially, more than 70 years, which is not only a difficult task but leaves much room for discretion and-as the Tribunal of Ascoli Piceno explicitly stated-for the 'skill of the advocates'. ${ }^{19}$ Nevertheless, this caselaw is promising in the sense that there will be some personal limits for bringing claims whereof the Court of Cassation will have to ensure a uniform interpretation.

In this context it is worth mentioning that the Tribunal of Ascoli Piceno in the same Order of 24 February 2017 awarded a financial reparation of $€ 30,000$ to the Comune di Castignano - the municipality where the crimes were committed-for the moral damage produced and inflicted on the public life of the Comune, and this claim was not subjected to any limiting considerations. In particular, this final section of the decision raises the fundamental question of the kind of reparation which comprises restitution, compensation and satisfaction, ${ }^{20}$ what seems especially significant with regard to the reparation accorded to a collective entity, in this case a municipality, rather than individual family members.

\footnotetext{
${ }^{16} \mathrm{Cf}$ Tribunale di Ascoli Piceno, Order of 8 March 2016, No 112/2015 (partial admittance), 22, Judge Foti relying on Corte di Cassazione, Judgment of 12 July 2006, No 15760/2006; Corte Costituzionale, Judgment of 6 May 1985, No 132/1985; Corte Costituzionale, Judgment of 14 July 1984, No 184/1984.

${ }^{17}$ Tribunale di Ascoli Piceno, Order of 24 February 2017, No 523/2015 (final admittance).

${ }^{18}$ See section III.2.

${ }^{19}$ Tribunale di Ascoli Piceno, Order No 523/2015 (n 17), 51, referring to Corte di Cassazione, Judgment of 8 October 2007, No 20987/2007. The original terms used by the Tribunal read: '[S]petta alle vittime ed alla intelligenza dei loro difensori, apprestare una difesa adeguata'. ('[I]t lies with the victims and the skill of their advocates to present an adequate defence' (translated by the authors)).

${ }^{20}$ See sections III.3. and V; Cf ILC, Draft Articles on State Responsibility, 2001 (n 4), Art 34.
} 


\section{Time Frame for Reparation Obligations}

The question of who can bring a claim involves the more general issue of the time frame for compensation claims. There are rules in national and international law reflecting the idea that legal peace can only be assured if after a certain lapse of time claims can no longer be raised. ${ }^{21}$ Such rules concern intertemporal law, statutory limitation, and forfeiture; each one was tackled by the Italian tribunals, but they were all dismissed as not applicable.

According to the principle of intertemporal law, ${ }^{22}$ only the law in force at the time when the controversial action occurred is applicable. This principle guarantees the certainty and stability of law, which is of utmost importance in both national and international law. It finds reflection in the idiom nullum crimen, nulla poena sine praevia lege poenali, which prohibits the retrospective application of criminal sanctions. In this context, the Italian tribunals rightly referred furthermore to the fact that 'since ever' international actors had tried to put limits to war crimes. ${ }^{23}$ They mention the International Geneva Conventions of 1864, 1906, 1929, and reaffirmed by those of 1949, which all substantially sanctioned crimes of war or what is now classified as crimes against humanity. While these arguments are plausible, the question remains whether criminal responsibility also implies civil responsibility: an obligation of individual reparation. In this context the Italian judges were categorical in stating that at the time the crimes were committed the "possibility of criminal-and even civil—sanctions was generally accepted'. ${ }^{24}$ This statement seems rather controversial as individual redress for war-related crimes was certainly

\footnotetext{
${ }^{21}$ Karin Oellers-Frahm, 'Judicial Redress of War-Related Claims by Individuals: The Example of the Italian Courts', in Ulrich Fastenrath et al (eds), From Bilateralism to Community Interest: Essays in Honour of Judge Bruno Simma (Oxford: OUP 2011), 1055-1078, at 1070; Carlo Focarelli, 'Diniego dell'immunità giurisdizionale degli Stati stranieri per crimini, jus cogens e dinamica del diritto internazionale', Rivista di diritto internazionale 91 (2008), 738-757; Alexander Orakhelashvili, 'State Immunity and International Public Order Revisited', German Yearbook of International Law 49 (2006), 327-365.

${ }^{22} \mathrm{Cf}$ Rosalyn Higgins, 'Some Observations on the Inter-Temporal Rule in International Law', in Jerzy Makarczyk (ed), Theory of International Law at the Threshold of the 21st Century (The Hague: Kluwer 1996), 173-181; Mieke van der Linden, 'The Inextricable Connection between Historical Consciousness and International Law', Select Proceedings of the ESIL 5 (2014), 447-460.

${ }^{23} \mathrm{Cf}$ Tribunale di Ascoli Piceno, Order No 523/2015 (n 17), 19 et seq; Tribunale di Ascoli Piceno, Order No 112/2015 (n 16); Tribunale di Piacenza, Judgment of 25 September 2015, No 723/2015.

${ }^{24}$ Tribunale di Ascoli Piceno, Order No 523/2015, (n 17), 25 stating that: ' $[L] a$ possibilità di sanzionare penalmente - e, ancor più, civilmente - fatti che (. . .) erano considerati criminosi (...) deve reputarsi norma internazionale comunemente accettata e riconosciuta' (translated by the authors).
} 
not an issue at the time at stake, namely before the adoption of the 1949 Geneva Conventions, and is under discussion, and thus not generally accepted, still today. ${ }^{25}$

With regard to prescription, the Italian judges are unanimous and refer, without further explanations, only to the Ferrini judgment of the Court of Cassation stating that there is no prescription for the 'credito risarcitorio da crimine di guerra', meaning that claims for reparation and compensation in such cases are, in principle, not submitted to time limitations. ${ }^{26}$ This follows from the fact that such claims 'reside in a principle of constitutional value, namely the right of the victims to complete compensation of damages, material or immaterial, resulting from the violation of fundamental human rights'. ${ }^{27}$ Although this statement seems to imply that there is no time limit for bringing reparation claims, it nevertheless refers to the right of 'victims', and this reference in combination with the more detailed interpretation of the 'danno parentale' given by the Tribunal of Ascoli Piceno sets a (biological) time limit, although not in the form of a prescription.

Furthermore, the objection concerning forfeiture of the claims ${ }^{28}$ was dismissed by the Italian judges. Forfeiture or 'implied waiver' of rights can be seen in the attitude of the Italian state after WWII, in particular in its renunciation to claim further reparation in the Peace Treaty of 1947 and later once more in the Bonn Agreements of 1961. This argument is, however, constantly dismissed by the Italian tribunals, arguing instead that the actual claims for reparation only concern immaterial damage and that such damage was not the subject matter of the Peace Treaty or the reparation agreements. $^{29}$

In sum it may be stated that 'legal peace', requiring, inter alia, respectively a definition of those who constitute the secondary victims of the crimes committed by Germany during WWII, will depend on the jurisdictional practice of the ordinary tribunals (in the last instance, the Court of Cassation) in interpreting what exactly amounts to 'danno parentale'. In this context the Tribunal of Ascoli Piceno's Order of 24 February 2017 sets a positive signal in the sense of requiring not only a mere

\footnotetext{
${ }^{25}$ Cf section III.1. See Christian Marxsen, 'What do Different Theories of Customary International Law Have to Say about the Individual Right to Reparation under International Humanitarian Law', Heidelberg Journal of International Law 78 (2018), 581-586, giving an introduction to the following 19 reports on that subject matter.

${ }^{26} \mathrm{Cf}$ Tribunale di Piacenza, Judgment No 723/2015 (n 23), para 4; Tribunale di Firenze, Judgment of 6 July 2015, No 2469/2015 (Furio Simoncioni) referring to Corte di Cassazione, Judgment of 11 March 2004, No 5044/04 (Ferrini); Cf for further decisions, Raffeiner, 'Jenseits der Staatenimmunität' (2016) (n 1), 468.

${ }^{27}$ Tribunale di Ascoli Piceno, Order No 523/2015 (n 17), 48, referring to Corte di Cassazione, Judgment No 15760/2006 (n 16); ItCC, Judgment No 132/1985 (n 16); ItCC, Judgment No 184/1984 (n 16).

${ }^{28} \mathrm{Cf}$ Burkhard Hess, 'Kriegsentschädigungen aus kollisionsrechtlicher und rechtsvergleichender Sicht', in Wolff Heintschel von Heinegg (ed), Entschädigung nach bewaffneten Konflikten: die Konstitutionalisierung der Welthandelsordnung (Heidelberg: Müller 2003), 107-205, at 146 et seq; Andrea Gattini, Le riparazioni di guerra nel diritto internazionale (Padua: CEDAM 2003), 247.

${ }^{29}$ Tribunale di Piacenza, Judgment No 723/2015 (n 23).
} 
family link, but also the proof of a concrete damage in order to have a claim admitted.

\section{Type of Reparation}

Finally, as a consequence of Sentenza 238/2014, the tribunals had to decide on the kind of reparation: either financial reparation or compensation-and the parameters of calculation - or mere satisfaction and/or a lump sum compensation to primary victims still alive or also to victims' family members. With a view to the first decisions of the Italian tribunals it has to be stated that no uniform scheme has been developed and that the decisions awarding monetary compensation raise serious concerns.

The cases where the victims themselves bring a claim may seem uncontroversial in justifying financial compensation. The few cases decided thus far demonstrate, however, that the amount of compensation awarded varies significantly. This raises questions not only with regard to the 'justice to be done' in the assessment of the suffering of the victim but also with regard to the lack of transparency concerning the calculation of the compensation amount. For example, two cases may be mentioned where the victims themselves brought a claim and where a compensation was awarded. ${ }^{30}$ In one of the cases an amount of $€ 50,000$ was awarded, in the other an amount of-only- $€ 30,000$ (plus interests of 4\% since 1945) was accorded without any explanation on how the amount was calculated. With a view to this opaque practice it might be preferable to award a prefixed amount of money as satisfaction or symbolic compensation because compensation is not only difficult to calculate but, as stated by the Italian tribunals, making good the suffering of the victims is impossible. Significant differences between the amounts of compensation awarded may raise further problems instead of leading to appeasement.

A second and rather more severe concern resulting from the first set of decisions following Sentenza 238/2014 relates to the proportionality of compensation awarded to the victims and the amount of compensation awarded to 'secondary victims', namely the heirs of victims. In this context a decision of the Tribunal of Florence is worth mentioning, which was delivered after the attempted conciliation solution under Article 185 of the Italian Code of Civil Procedure failed. ${ }^{31}$ In this case, the Tribunal of Florence fixed an amount of $€ 325,000$ (plus interests of $4 \%$ running from 1945 ) as compensation for each of the daughters of the victim. ${ }^{32}$ In another case,

\footnotetext{
${ }^{30}$ Tribunale di Firenze, Judgment of 6 July 2015, No 2468/2015 (Duilio Bergamini) and Judgment No 2469/2015 (Furio Simoncini) (n 26). Cf Oellers-Frahm, 'A Never-Ending Story' 2016 (n 8), 199. In the same vein, Corte di Cassazione, Judgment of 13 January 2017, No 762/2017 and Judgment of 29 July 2016, No 15812/2016.

${ }^{31}$ See section II.

${ }^{32}$ Tribunale di Firenze, Judgment of 22 February 2016, No 144740/2009 (Donati).
} 
decided by the Tribunal of Ascoli Piceno, the spouses and children of a victim were each awarded compensation of between $€ 130,000$ and $€ 150,000 .{ }^{33}$ Already these two examples raise the question of 'doing justice', in that it is extremely problematic and hardly tolerable that family members of a victim, more than 70 years after the underlying crime, were awarded a compensation amount significantly higher than that awarded to the victims themselves. It demonstrates that justice requires a fair balance between the compensation awarded to the primary and the secondary victims and that those who directly suffered the crime, and the compensation awarded to them, should set the standard for compensation awarded to family members.

These considerations support the proposals concerning a general limitation of financial compensation in two directions, first to award financial compensation to primary victims only, and second to provide for a prefixed amount, as has been done with regard to Russian prisoners of war. ${ }^{34}$ If, however, the next of kin should be accorded a right to compensation, the amount should in any case not exceed the sum fixed for a primary victim. As 'reparation', in the original sense of the term, cannot be made, satisfaction and a symbolic amount of financial compensation seems more adequate, not least when considering the length of time that has elapsed. From this perspective, the idea of a fund established by both Germany and Italy ${ }^{35}$ would probably best serve the aim of giving voice to the victims and their heirs without raising new problems by awarding financial compensation on grounds that lack sufficient transparency, ${ }^{36}$ as well as striking a fair balance between the compensation awarded to primary and secondary victims. The creation of a fund would, however, require the consent of Germany, which as things stand seems rather unlikely.

\section{Implications of the Italian Decisions}

\section{a) Precedential Effects}

The denial of immunity from jurisdiction resulting from Sentenza 238/2014 will have implications also beyond the Italian context since questions of reparation for war-related claims remain unsettled also with regard to other armed conflicts. ${ }^{37}$ Such cases are not only on the docket of national courts but of international courts as well,

\footnotetext{
${ }^{33}$ Tribunale di Ascoli Piceno, Order No 523/2015 (n 17).

${ }^{34}$ On 20 May 2015 the German government decided to pay a financial compensation of $€ 2,500$ to each of the approximately 4,000 Russian prisoners of war still alive, which is explicitly characterized as symbolic compensation. Cf section VI.

${ }^{35}$ See Stefan Kadelbach, chapter 'State Immunity, Individual Compensation for Victims of Human Rights Crimes, and Future Prospects', and Francesco Francioni, chapter 'Overcoming the Judicial Conundrum', in this volume.

${ }^{36}$ See section V.

${ }^{37}$ Cf Christian Tams, chapter 'A Dangerous Last Line of Defence', in this volume.
} 
in particular the European Court of Human Rights (ECtHR) and the Inter-American Court of Human Rights (IACrtHR). These issues can only summarily be addressed in the present context, but they are of high relevance not only on the national, but also on the international level because they gain significance as precedents particularly regarding the following issues. ${ }^{38}$

In the first place there is the fundamental question of whether individuals have at all a right to claim compensation or reparation for war-related crimes, a question that is not explicitly settled in international law. ${ }^{39}$ State practice resulting from the history of ending wars shows that peace treaties (usually) provided for reparation schemes covering all claims of any kind in order to foster peaceful future relations. There are only a few precedents where victims of war crimes were seeking or even accorded reparation for their personal suffering during war. ${ }^{40}$

Only recently can a development be observed concerning individual claims requiring reparation or compensation for war-related crimes brought before national courts, but also before international human rights courts, as there is no clearly defined demarcation between human rights and humanitarian law. ${ }^{41}$ Although these developments have some merit, because war-related crimes should not go unpunished, the fundamental question remains: whether this is an acceptable way to cope with war-related claims as thousands of claims originating from all sides of the

\footnotetext{
${ }^{38}$ Giuseppe Cataldi, 'Immunités juridictionnelles des Etats étrangers et droit de l'homme: quel équilibre entre les valeurs fondamentales de l'ordre national et le droit international coutumier?', in James Crawford et al (eds), The International Legal Order: Current Needs and Possible Responses (Leiden: Brill Nijhoff 2017), 571-590.

${ }^{39}$ Christian Tomuschat, 'Individual Reparation Claims in Instances of Grave Human Rights Violations: The Position under General International Law', in Albrecht Randelzhofer/Christian Tomuschat (eds), State Responsibility and the Individuals (The Hague: Martinus Nijhoff 1999), 1-25; Alessandro Bufalini, 'La riparazione per gravi violazioni dei diritti umani e del diritto umanitario tra rinuncia dello stato e diritto individuale', in Andrea Spagnolo/Stefano Saluzzo (eds), La responsabilità degli stati e delle organizzazioni internazionali (Milan: Ledizioni 2017), 375-391; Enzo Cannizzaro, 'Is There an Individual Right to Compensation?', in Denis Alland et al (eds), Unité et diversité du droit international (Leiden: Brill Nijhoff 2014), 495-502. See also Christian Tomuschat, chapter 'The Illusion of Perfect Justice', in this volume; Marxsen, 'Different Theories of Customary International Law' 2018 (n 25) and the other reports referred to in n 25.

${ }^{40}$ See Roland Bank/Elke Schwager, 'Is There a Substantive Right to Compensation for Individual Victims of Armed Conflict against a State under International Law' German Yearbook of International Law 49 (2006), 367-411, who propose to combine the conclusion of reparation agreements between the states concerned with a waiver of individual claims what seems to indicate a feasible solution; the individual claims were thus merged with the reparation provisions in the peace treaties and the individuals were then compensated by the state which received the reparation payments.

${ }^{41}$ In its Advisory Opinion concerning Legal Consequences of the Construction of Wall in the Occupied Palestinian Territory, the ICJ had stated in this context: 'As regards the relationship between international humanitarian law und human rights law, there are thus three possible situations: some rights may be exclusively matters of international humanitarian law; others may be exclusively matters of human rights law; yet others may be matters of both these branches of international law', (ICJ, Legal Consequences of the Construction of Wall in the Occupied Palestinian Territory, Advisory Opinion of 9 July 2004, ICJ Reports 2004, 13, para 106).
} 
involved actors may put at risk peaceful relations between former enemies. ${ }^{42}$ This question, which is still pending before the ECtHR, ${ }^{43}$ was met with silence by the Italian tribunals as they merely referred to the Ferrini Judgment of the Court of Cassation, which did however, not concern this issue as such but only the question of statutory limitation. ${ }^{44}$ A further consequence of admitting individual redress of war-related violations of human rights may be that states involved in a war or armed conflict would abstain from accepting lump sum agreements when facing additional individual claims.

The fact that the Italian tribunals did not address the issue of admissibility of individual claims at all may be understood in the sense that this question is not controversial and will not play a role in Italian courts and tribunals inviting thus victims of war crimes to claim reparation, particularly because Italy admits such claims as it does not feel bound by the rule of state immunity or other relevant issues, such as intertemporal law, statutory limitation, forfeiture or waiver. These principles have not been admitted as limiting factors to individual claims, so that Italy may appear as an El Dorado for individuals seeking redress for war-related reparation claims and will not only serve as a precedent setter but also as the preferred forum for cases concerning reparations and compensation for war crimes that are allegedly unsettled and neither concern Italian nationals nor acts committed on Italian territory. ${ }^{45}$

\section{b) Forum Shopping (Universal Jurisdiction)}

The concern of forum shopping is in fact not only a theoretical one; there are cases in which Italian courts and tribunals were seized with cases lacking any relation to Italy. One of the most prominent and to a degree 'leading' cases in this context is the Distomo case, ${ }^{46}$ which concerned a claim for execution of a decision delivered by

\footnotetext{
${ }^{42} \mathrm{Cf}$ in this context, Karin Oellers-Frahm, 'A Regional Perspective on the Convergence and Conflicts of Human Rights and International Humanitarian Law in Military Operations: The European Court of Human Rights', in Erika de Wet/Jann Kleffner (eds), Convergence and Conflicts of Human Rights and International Humanitarian Law in Military Operations (Pretoria: Pretoria University Law Press 2014), 333-363; and Dinah Shelton, 'Humanitarian Law in the InterAmerican Human Rights System', ibid, 365-393.

${ }^{43}$ Cf ECtHR, Georgia v Russia II, Application No 38263/08 of 11 August 2008, where the ECtHR will have to decide whether international humanitarian law is exclusively applicable so that the case cannot be decided by the ECtHR in the context of an individual complaint.

${ }^{44}$ See section III.2.

${ }^{45}$ See also Bernardo Giorgio Mattarella, chapter 'Sentenza 238/2014', in this volume.

${ }^{46}$ Corte di Cassazione, Judgments of 29 May 2008, No 14199/2008 and of 20 May 2011, No 11163/2011, on which see: Micaela Frulli, “"The Times they are A-Changing”- - the Italian Court of Cassation Denies Germany Immunity from Execution to Allow Compensation to War Crimes' Victims', Journal of International Criminal Justice 9 (2011), 1129-1142. The execution proceedings concerned the implementation of the Tribunal of Livadia (Greece) of 30 October 1997 against Germany and Deutsche Bahn AG awarding reparation for war crimes committed by German
} 
Greek courts for German war-related crimes committed in Greece. Although this case concerned only the execution of the decision on the costs of the proceedings before Greek tribunals, the fact that the Italian Court of Cassation admitted execution on German property located in Italy set a new trend. The Court of Cassation did not at all tackle questions of state immunity or more generally questions of jurisdiction with regard to the execution of foreign judgments in Italy but merely referred to Article 64 of the Law No 218 of 31 May 1995 concerning the Italian international private law system, which inter alia requires that the foreign judgment does not run contrary to the national 'ordre public' for giving leeway for execution.

Italian tribunals were also confronted with individual reparation claims resulting from armed conflicts, such as the one that occurred between 1991 and 1995 in the former Yugoslavia. Thus, the criminal division of the Court of Cassation, for example, denied immunity to Serbia in relation to a request for compensation brought by the heirs of Italian victims of war crimes committed in the Yugoslav armed conflict. ${ }^{47}$ In two further decisions, the Court of Cassation recognized that Iran was not entitled to immunity for acts amounting to crimes against humanity, ${ }^{48}$ although in the cases before it the court denied exequatur to the judgments of US courts that had awarded damages against Iran for reasons concerning the requirements for exercising civil jurisdiction under the relevant Italian law. ${ }^{49}$

What is interesting in these cases is the fact that the Italian courts and tribunals do not refer to principles such as universal jurisdiction, which in particular in cases concerning war crimes is often referred to, but only rely on national law, namely Law No 218/1995, which regulates the Italian system of international private law. In the cases concerning civil claims, reference to the principle of universal jurisdiction would in fact not have been appropriate. Indeed, universal jurisdiction empowers states to exercise criminal jurisdiction regardless of where the alleged crime was

troops at Distomo which was the starting point of the controversy on the existence of state immunity in cases of serious violations of human rights. This decision was upheld by the Greek Supreme Court on 4 May 2000, but it was eventually not enforced because of the refusal by the Greek Ministry of Justice to authorize execution. For an overview over the controversy see Andrea Gattini, 'The Dispute on Jurisdictional Immunities of the State before the ICJ: Is the Time Ripe for a Change in the Law?', Leiden Journal of International Law 24 (2011), 173-200, with bibliographical references.

${ }^{47}$ Corte di Cassazione, Judgment of 29 October 2015, No 43696/2015 (Opačić); cf, in this context, Riccardo Pavoni, 'How Broad is the Principle Upheld by the Italian Constitutional Court in Judgment No. 238?', Journal of International Criminal Justice 14 (2016), 573-585, at 577. See also Paolo Palchetti, chapter 'Right of Access to (Italian) Courts über alles?', in this volume.

${ }^{48}$ Corte di Cassazione, Judgment of 28 October 2015, No 21946/2015 (Flatow); Corte di Cassazione, Judgment of 28 October 2015, No 21947/2015 (Eisenfeld). See also Riccardo Pavoni, chapter 'A Plea for Legal Peace', in this volume.

${ }^{49}$ Italian Law 31 May 1995, No 218. Art 64 and Art 3(1-2) require that (1) the foreign judge was competent according to the Italian legal order (which was not the case with regard to the US Foreign Immunities Act); (2) that the foreign state was represented in the forum state (which was not the case because the diplomatic relations between the US and Iran were interrupted since 1979); and finally that (3) the illegal act, which did not occur in the US but in Israel, had been the subject matter of criminal proceedings in the US (which was also not the case). 
committed and regardless of the accused's nationality, country of residence or any other relation with the prosecuting entity. ${ }^{50}$ Whether criminal jurisdiction would include civil jurisdiction, as was stated by the Tribunal of Ascoli Piceno, is not generally admitted ${ }^{51}$ and was explicitly contradicted by the Court of Cassation in the two aforementioned cases concerning the execution of US decisions against Iran. ${ }^{52}$ In these cases, the Court of Cassation stated that 'what follows from Sentenza $238 / 2014$ is not the recognition of a principle of universal civil jurisdiction in cases for compensation of delicta imperii, but only the inapplicability of the customary rule of immunity from civil jurisdiction in cases concerning compensation for damages deriving from the commission on the territory of the forum state of crimes against humanity' (paragraph 5, 'considerato in diritto' of both decisions (translated by the author)). Accordingly, universal jurisdiction would not constitute a legal basis for the competence of Italian courts and tribunals to admit compensation cases, as such competence derives only from Italian international private law rules. ${ }^{53}$ As, however, the primary hurdle for admitting civil cases against foreign states has been lifted by Sentenza 238/2014, namely immunity from jurisdiction, exequatur of foreign decisions is governed primarily by Articles 3 and 64 of Law No 218/1995 or, in cases involving EU member states, the Brussels Ia Regulation as amended in 2015. The application of this regulation would, however, require that the acts concerned do not constitute acts of state authority, namely acta iure imperii. ${ }^{54}$ Thus, the Italian courts and tribunals, by removing the hurdle of state immunity,

\footnotetext{
${ }^{50} \mathrm{Cf}$ Gerhard Werle/Florian Jeßberger, Principles of International Criminal Law (Oxford: OUP $3^{\text {rd }}$ ed 2014).

${ }^{51}$ In Tribunale di Ascoli Piceno, Order No 523/2015 (n 17), the Tribunal referred to Art 7 of the European Convention on Human Rights in the context of non-retroactivity of criminal law and the exception in para 2 of Art 7 concerning punishment for acts considered as criminal 'according to the general principles of law recognised by civilised nations'. The Tribunal of Ascoli Piceno stated in a categorical manner that this provision 'offered the possibility of criminal-and even civilsanctions of the war crimes' at stake (Judgment of 24 February 2017, at 25).

${ }^{52}$ Corte di Cassazione, Judgments Flatow and Eisenfeld (n 48).

${ }^{53}$ These rules are similar to the rules on recognition of foreign judgments in many states, eg section 238 of the German Code on Civil Procedure. The main prerequisites concern, on the one hand, some territorial link, namely that the defendant has at least a representation authorized to appear before Italian courts according to Art 77 of the Italian Code on Civil Procedure (Art 3 of Italian Law, 218/1995 (n 49)). On the other hand, the recognition of the foreign judgment depends on the following requirements: (1) that the judge delivering the judgment was competent to decide on the case according to the jurisdictional principles of the Italian legal order; (2) that the defendant was informed of the claim brought against him according to the forum law; (3) that the parties appeared before the court according to the forum law or non-appearance was officially stated; (4) that the decision has become binding under the forum law; (5) that the decision is not contrary to a binding decision of an Italian court; (6) that no proceedings are pending before an Italian judge concerning the same subject matter and the same parties and brought before the court prior to the foreign proceedings; and (7) that the decision does not produce effects contrary to the ordre public (Art 64 of Italian Law 218/1995 (n 49)).

${ }^{54}$ See Andreas Zimmermann, chapter 'Would the World Be a Better Place If One Were to Adopt a European Approach to State Immunity?', in this volume.
} 
offer an attractive forum for cases claiming compensation from foreign states or recognition of foreign judgments against states.

Although Italian courts and tribunals are thus a promising forum for cases concerning claims against states, the fact remains that plaintiffs before Italian courts have only succeeded in achieving a partial, or maybe even only a symbolic, victory. This is due to the fact that the question of execution of a judgment after a decision awarding compensation or a decision on recognition of a foreign judgment awarding compensation is still unsettled and poses even higher barriers than the one concerning the issue of jurisdiction. In this context the question of state immunity re-appears with regard to execution of the judgments, and a development with regard to practice for denying immunity from execution comparable to that concerning jurisdictional immunity has not occurred yet.

\section{Enforcing a Successful Adjudication: The Constitutional Court Versus 'the Last Bastion of State Immunity'?}

It remains to be seen whether, and if so when, all of the judgments by Italian courts considered so far will be enforced, thus making reparations to the victims effective. After adjudication on one's claim becomes final, enforcement traditionally occurs either willingly by the respondent or by way of specific execution proceedings established under domestic law. However, if the respondent is a foreign state, general international law provides for a procedural bar preventing the judiciary of the forum state from enabling enforcement. In the absence of an express waiver of immunity by the foreign state, this guarantee is generally accorded to every sovereign state and is called 'immunity from execution'. Unlike 'immunity from adjudication', the approach towards lifting immunity from execution has been far more restrictive in state practice. This brings up the question of whether, following Sentenza 238/2014, Italian ordinary courts are under obligation to deny Germany immunity from execution or, conversely, whether they still ought to abide by it and, if so, on what basis.

For the time being, this question has been dealt with by the Court of Appeal of Milan and by the Tribunal of Rome. More recently, the Court of Cassation delivered the final judgment on the question previously decided by the Court of Appeal of Milan, thereby apparently setting a point in favour of the doctrine whereby immunity from execution should be upheld even after denial of immunity from adjudication. Before these pronouncements, however, other courts adjudicating on the merits of the actions for damages related to crimes committed by Germany on Italian soil already suggested a different nature existing between immunity from adjudication and immunity from execution. In particular, in its Judgment No 2468 of 6 July $2015,{ }^{55}$ the Tribunal of Florence maintained that the exercise of civil jurisdiction did

${ }^{55}$ Tribunale di Firenze, Judgment No 2468/2015 (n 30). 
not per se pose a risk to the sovereignty of the German state since it merely implied a judgment having a declaratory nature ('sentenza di mero accertamento e condanna') and not necessarily entailing execution.

In this respect, however, the judgments mentioned above provided for more nuanced solutions. In its ruling of 27 January 2015, ${ }^{56}$ the Court of Appeal of Milan refused to take measures of constraint on Villa Vigoni-a cultural property belonging to Germany and located in Italy_-being conscious of the risk of infringing upon the right to state immunity from enforcement. In fact, as already acknowledged by the ICJ in its Jurisdictional Immunities Judgment (paragraphs 113-120), immunity from adjudication and immunity from execution are subjected to different legal regimes under customary international law. ${ }^{57}$ While in the field of jurisdictional immunity courts ought to scrutinize the nature of an act as iure imperii or iure gestionis, when applying immunity from execution, judges ought to check whether the property against which enforcement measures should be taken is being used for governmental or commercial purposes. Therefore, insofar as used for non-commercial governmental purposes, Villa Vigoni could not be seized or subjected to provisional measures even after Sentenza 238/2014. ${ }^{58}$ The judgment of the ItCC, in fact, concerned a question on the application of immunity from adjudication only. ${ }^{59}$ Therefore, Article 24 of the Italian Constitution could not extensively be interpreted as providing for a right to a judge as including also effective enforcement, otherwise such a right would have encroached upon assets devoted to a public service (publicis usibus destinata). Yet, the ground for declaring the invalidity of the judicial mortgage over Villa Vigoni by the Court of Appeal of Milan was the ineffectiveness of the instrument permitting enforcement ('titolo esecutivo'), that is, the non-enforceability of Greek judgments in Italy after the ICJ

\footnotetext{
${ }^{56}$ Corte d'Appello di Milano, Judgment of 27 January 2015, No 1278/2015.

${ }^{57}$ See Michael Wood, 'Immunity from Jurisdiction and Immunity from Measures of Constraint'; Chester Brown/Roger O'Keefe, 'Part IV State Immunity from Measures of Constraint in Connection with Proceedings Before a Court, Preliminary Material', both in Roger O'Keefe et al (eds), The United Nations Convention on Jurisdictional Immunities of States and Their Property (Oxford: OUP 2013), 13-18 and 288-293. Cf also, ILC, Report on the Work of the thirtieth session (1978), UN Doc A/33/10, 154, para 23. See, in particular, 'Concurring Opinion of Judge Pellonpää joined by Judge Bratza in Al Adsani v United Kingdom', in Elihu Lauterpacht et al (eds), International Law Reports 123 (Cambridge: CUP 2003), 45-49, arguing that even in the US, where the Foreign Sovereign Immunities Act (FSIA) has been amended so as to allow US citizens to raise damage claims based, inter alia, on torture against specifically designated states, immunity from execution has ultimately not been removed.

${ }^{58}$ As regards other similar cases, it ought to be pointed out that execution or attachment measures against properties situated in the forum state and serving as cultural institutions were generally prohibited, as the practice of Swiss courts and of the Hellenic Republic shows. See August Reinisch, 'European Court Practice Concerning State Immunity from Enforcement Measures', The European Journal of International Law 17 (2006), 803-836, at 824; more recently see: Jean-Marc Thouvenin/Victor Grandaubert, 'The Material Scope of Immunity from Execution', in Tom Ruys et al (eds), The Cambridge Handbook of Immunities and International Law (Cambridge: CUP 2019), 245-265, at 260 mentioning also French case-law.

${ }^{59}$ ItCC, Judgment 238/2014 (n 7), para 1.2.
} 
Judgment. The opinion of the Court of Appeal was substantially confirmed in June 2018 by the Court of Cassation. However, the Italian Supreme Court overruled the reasons on the basis of which the lower judge declared the invalidity of the legal charge: the question was in fact not the ineffectiveness of the aforementioned instrument to permit enforceability, as would have been the case if the Italian judiciary would have abided by the ICJ Judgment (paragraphs 121-131); on the contrary, according to the Supreme Court, the instrument ('titolo esecutivo') remains effective, but allows for enforceability only against those assets of the Federal Republic of Germany that are not devoted to public purposes. This not being the case, the lower judge should have declined jurisdiction and the judicial mortgage should have been cancelled from the land register. ${ }^{60}$ Therefore, one should conclude that the Supreme Court reversed the lower judge decision to the extent to which the Court of Appeal, building upon the ICJ Judgment, had made the exequatur granted to Greek judgments null and void, even though it could only adjudicate upon the legality of the mortgage.

In this respect, the reasoning by the Court of Cassation is only partly consistent with a decision by the Tribunal of Rome, handed down on 20 May 2015 and upheld by the same Court of Cassation on 3 September 2019. In fact, the Tribunal overturned a 2012 order by the enforcement judge of the same Tribunal of Rome according to which an action for execution in Italy of Greek judgments against Germany could not be advanced or undertaken. For their execution Greek claimants had attempted to attach credits owed by the Italian Ferrovie dello Stato (the Italian state-owned railway company) to Deutsche Bahn $A G$, the German railway company and a private corporate body the shares of which are currently held by the Federal Republic. The Tribunal of Rome argued that, after Sentenza 238/2014, the order already issued by the enforcement judge on the basis of the ICJ Judgment was null and void and that execution proceedings of the underlying judgment on the merits, awarding the victims a sum of nearly $€ 50$ million, could be resumed. Objections brought forward by Deutsche Bahn AG before the Court of Cassation concerning the fact that it could not be held responsible for the crimes committed by Germany and that the underlying judgment had not considered this aspect were dismissed as inadmissible. The reason being that in a procedure on execution, questions of this kind could not be raised as they are part of the proceedings on the merits. Only in the case of a serious error in law that aspect could have been reviewed in the execution procedure. However, such an error did not exist in the case at stake as it is clear that the Italian legal order does not grant immunity from jurisdiction in cases concerning violations of human rights, pursuant to Sentenza 238/2014. Accordingly, not only the judge on the merits, but also the enforcement judge is obliged to dismiss

\footnotetext{
${ }^{60}$ Corte di Cassazione, Judgment of 8 June 2018, No 14885/2018, which goes back to Corte di Cassazione, Judgment of 12 January 1996, No 173/1996. See the case note by Olivia Lopes Pegna, "Giù le mani da Villa Vigoni: quale tutela "effettiva" per le vittime di gravi crimini compiuti da Stati esteri', Rivista di diritto internazionale 4 (2018), 1237-1244; Pierfrancesco Rossi, 'The Aftermath of the Italian Constitutional Court Judgment No. 238 of 2014 in Exequatur and Enforcement Proceedings', Italian Yearbook of International Law, 28 (2018), 455-459.
} 
objections based on state immunity and exercise jurisdiction. This implies, in essence, that the grant of exequatur of Greek judgments by Italian courts, being of an adjudicatory nature, was deemed legitimate and in line with Sentenza 238/2014. Nonetheless, the Supreme Court's judgment applies 'without prejudice to whether immunity from execution applies, a question which will potentially be dealt with once the very execution proceedings will be started'. ${ }^{61}$ In other words, from a domestic civil procedural point of view, the execution proceedings in which the unaffected question on whether Deutsche Bahn AG credit liabilities can legitimately be attached by the Italian state might be addressed, start in a later moment and not already when the enforcement judge declares a judgment enforceable. Therefore, the fact that the enforcement judge cannot decline jurisdiction on grounds of sovereign immunity does not yet say anything about whether or not the properties of the foreign state can legitimately be attached.

In this respect, however, from an international law perspective of immunity application, whereas Villa Vigoni is a German property serving sovereign purposes and in fact deserves enjoyment of immunity from execution, the credit liabilities of the German railway company towards the Italian railways could hardly be treated as fulfilling non-commercial purposes. In this respect, Italian ordinary courts are called upon to give a consistent interpretation of both the existing customary international law and the manifold case-law of the ItCC and to assess whether immunity from measures of constraint should be lifted. Before Sentenza 238/2014, the Corte Costituzionale already dealt with the question of the compatibility of immunity from execution with the right to effective judicial protection, ie to enforcement of a judgment as encompassed in Article 24 of the Italian Constitution. ${ }^{62}$ In particular, with its Judgment No 329/1992 the ItCC declared unconstitutional a legal provision dating back to 1926 that prevented the Italian judiciary from confiscating the goods of a foreign state without prior authorization from the Minister of Justice. ${ }^{63}$ By leaving it up to the discretion of the executive power, the legal provision at hand was deemed to be contrary to the (then) current state of customary international law and therefore contrary to Article 10(1) of the Italian Constitution since it might have

\footnotetext{
${ }^{61}$ Tribunale di Roma, Judgment of 20 May 2015, No 11069/2015, (translated by the authors). So also: Corte di Cassazione, Judgment of 3 September 2019, No 21995/2019. (para 19). Cf Cristina M Mariottini, 'Case Note: Deutsche Bahn AG v. Regione Stereá Ellada', American Journal of International Law 3 (2020), 486-493; Barbara De Santis, 'Profili di giurisdizione nell'esecuzione forzata sui beni dello Stato estero', Judicium-Il processo civile in Italia e in Europa, 30 April 2020; Luca Baiada, 'Ancora sull'esecuzione su beni di Stato estero', Questione Giustizia, 30 September 2019, according to whom the Court of Cassation's judgment consistently draws upon Sentenza 238/2014 to bring about the lifting of immunity from execution. Contra see: Giorgia Berrino, 'La Corte di Cassazione torna sul tema delle immunità giurisdizionali degli Stati stranieri e dei loro beni', Rivista di diritto internazionale, 3 (2020), 844-858, at 856-857.

${ }^{62}$ On Article 24 of the Italian Constitution and enforcement proceedings see: Luigi Paolo Comoglio, 'Principi costituzionali e processo d'esecuzione', Rivista di diritto processuale 2 (1994), 450-469.

${ }^{63}$ Corte Costituzionale, Judgment of 2 July 1992, No 329/1992.
} 
prevented ordinary courts from lifting immunity from execution also for acta iure gestionis. ${ }^{64}$ At the same time, the prior authorization of the Minister also encroached upon the individual right to a judge as protected by Article 24 of the Italian Constitution, since 'the right of the individual to a judicial remedy requires that the existence of the legal conditions to file a lawsuit before a court be ascertained by a judge according to the procedural guarantees set out by the law', and not by a member of the executive power. Having said that, the ItCC clarified:

[I]t does not deny that, within the context of international relations with foreign states, the fundamental right to judicial protection can be limited beyond what customary international law provides, as introduced through Article 10 of the Italian Constitution. However, this limitation ought to be justified by a public interest potentially outweighing the principle set out in Article 24 of the Italian Constitution, which is one of the supreme principles of the constitutional order (cf. Judgment No 18/1982). Moreover, the norm providing for a limitation to the individual right at hand shall undergo a rigorous assessment of this interest in the light of the specific aspects of the case. ${ }^{65}$

That Article 24 of the Italian Constitution does not provide for an absolute right and can be outweighed by a higher public interest has been further confirmed by the ItCC in its Sentenza 238/2014. However, the sacrificing of the right to a judge should not be deemed disproportionate to the interest pursued and the means employed. Such an interest could not be assessed in the case regarding immunity from adjudication, thus making the right to a judge prevail over state immunity. ${ }^{66}$ It remains to be seen whether a different balancing operation could be carried out if immunity from execution was at stake.

As we have seen, pursuant to Sentenza 238/2014, mere compliance with customary international law, as well as the promotion of comity and good relations with other states, might provide for a legitimate aim to restrict the right to a judge but cannot per se constitute a proportionate means for justifying such a restriction. ${ }^{67}$ Therefore, the decision adopted by the Court of Appeal of Milan would probably not be confirmed in the same way by the ItCC. On the contrary, the final decision by the Court of Cassation appears to be much more in conformity with Sentenza 238/2014, as it does not uphold immunity from execution as such but only to the extent to which the properties of the foreign state at stake truly serve a public interest. This leaves open the practical question of what properties different from Villa Vigoni do allow for measures of constraint to be taken and, in particular, whether the credit liabilities of Deutsche Bahn AG or other German government-owned companies may legitimately be attached as assets within the property of a foreign State.

\footnotetext{
${ }^{64}$ Similarly in the US, as pointed out by Reinisch, 'European Court' 2006 (n 58), 814.

${ }^{65}$ ItCC, Judgment No 329/1992 (n 63), (translated by the authors).

${ }^{66}$ ItCC, Judgment 238/2014 (n 7), para 3.4.

${ }^{67} \mathrm{The}$ ItCC's reasoning is radically different from that of the ECtHR adjudicating on the compatibility of immunity with Article 6 ECHR. The Strasbourg Court, in fact, did not hesitate to consider domestic decisions to accord immunity as pursuing a legitimate aim and as being proportionate. On these judgments see, inter alia, Matthias Kloth, Immunities and the Right of Access to Court under Article 6 ECHR, (Leiden/Boston: Martinus Nijhoff 2010), 21-158.
} 
In this respect, however, one should also keep in mind that a judicial mortgage over part of the property of Villa Vigoni was recorded again on 11 November 2019 after the Tribunal of Sulmona had issued its Order of 2 November 2017. Therefore, even though the ICJ Judgment qualified Villa Vigoni as fulfilling 'entirely' noncommercial purposes (para. 119), Italian enforcement tribunals may soon be required to decide otherwise, ie that execution can be carried out as regards part of the real property of the cultural centre, considering its various uses. ${ }^{68}$

The ItCC could also argue that immunity from execution as such does not bring about an absolute and therefore disproportionate sacrifice of the right to a judge, since adjudication on the merits ('la verifica giurisdizionale', as the ItCC literally called it) had already been enabled after denial of immunity from adjudicatory jurisdiction. ${ }^{69}$ Quite surprisingly, such an outcome is hinted at in the Order of the Tribunal of Florence No 85/2014, by means of which it referred the question of constitutionality to the ItCC. There the Tribunal maintained that immunity from execution might not be in breach of Article 24 of the Italian Constitution since one could have reasoned as follows: 'While Article 24 of the Italian Constitution requires an assessment on the merits and a conviction for such serious crimes, (...) the same provision sets a limit in terms of execution, [being] (...) only this portion of jurisdiction, if exercised, intrusive on State sovereignty. ${ }^{, 70}$ However, upholding the benefit of immunity from execution in these terms would display an utmost cynicism towards the victims' destiny, ${ }^{71}$ thus making Sentenza 238/2014 a Pyrrhic victory. ${ }^{72}$ A sounder approach appears to conform to the first solution, according to which immunity from execution should be treated no longer as a taboo, but only to the extent that assets used for commercial purposes are concerned.

On the other hand, the ItCC might deny altogether Germany immunity from execution either by entrusting itself with the power to reinterpret general international law differently from that of the ICJ or, alternatively, by following the path of Sentenza 238/2014 and thereby discarding international law in favour of domestic constitutional law.

As to the first option, for which the ItCC has no constitutional mandate, it could follow an approach not completely unknown under customary international law,

\footnotetext{
${ }^{68} \mathrm{Cf}$ for instance Pål Wrange, 'Case Note: Sedelmayer v. Russian Federation', American Journal of International Law 2 (2012), 347-353, in which the Swedish Supreme Court allowed enforcement over a Russian real property being the building at stake only to a limited extent and not in considerable part' used for official purposes.

${ }^{69}$ Cf Paolo Palchetti, chapter 'Right of Access to (Italian) Courts über alles?', in this volume.

${ }^{70}$ Tribunale di Firenze, Order of 21 January 2014, No 85/2014 (translated by the authors).

${ }^{71}$ So also Paolo Palchetti, 'Italian Concerns after Sentenza 238/2014: Possible Reactions, Possible Solutions', VerfBlog, (11 May 2017), available at http://verfassungsblog.de/italian-concerns-aftersentenza-2382014-possible-reactions-possible-solutions/.

${ }^{72}$ This epithet is owed to the US District Court Judge Royce C Lamberth in Eisenfeld v Iran, US, 172 F.Supp.2d 1, 9 (D.D.C. 2000).
} 
whereby enforcement is regarded as a 'logical consequence' of adjudication and therefore could deny Germany immunity from enforcement measures. ${ }^{73}$ This outcome could be justified also by means of an a contrario argument, taking into account recent Italian state practice. In fact, even if it is true that Italian courts have so far always complied with the rule of immunity from execution, legislation passed most recently shows that neither the executive nor the legislative powers were fully convinced of the deeply rooted nature of this customary rule on the matter. For this reason, immediately following Sentenza 238/2014, the Italian parliament introduced Article 19-bis into Law No 162 of 10 November $2014,{ }^{74}$ by virtue of which the bank and postal accounts of a foreign state's diplomatic mission or consular posts are exempt from attachment and execution, insofar as the head of the diplomatic mission of the foreign state unilaterally declares that the accounts are in use for the institutional purposes of the mission itself. ${ }^{75}$ In so doing, it appears that Italian political bodies were uncertain as to the very existence of a rule of customary international law providing foreign states with immunity from execution whenever their property serves a sovereign purpose; alternatively, they probably feared that the Italian judiciary would have been able to provide for a different interpretation of general international law, thus potentially engaging Italy's responsibility for an internationally wrongful act. However, similar to the case adjudicated by the ItCC in $1992,{ }^{76}$ in precluding the assessment by the judiciary regarding the correctness of the unilateral declaration by the ambassador, the right of access to justice as

\footnotetext{
${ }^{73}$ In particular, Swiss courts for a given period of time considered that execution should simply follow from adjudication on the merits so that once adjudication against a foreign state is undertaken, enforcement should also be possible. In the Netherlands one could recall a rather isolated and outdated pronouncement by the Dutch Supreme Court (1973), by means of which any measure of enforcement against foreign state properties situated in the territory of the forum state could be taken. In Turkey, a number of decisions have held that foreign property can be seized or attached. See, for a general survey of state practice on immunity from execution, Hazel Fox/Philippa Webb, The Law of State Immunity (Oxford: OUP $3^{\text {rd }}$ ed 2013), 482-490; Reinisch, 'European Court' 2006 (n 58), 809-811; 813.

${ }^{74}$ Similarly, while a decision was pending before the ICJ, the Italian government issued the Law-decree No 68/2010, which suspended the effectiveness of the enforcement order ('titolo esecutivo') upon assets belonging to foreign states until the judgment. See, on the nature of this law decree and its compatibility with the Italian Constitution, Francesco Salerno, 'Esecuzione in Italia su beni di Stati stranieri: il decreto-legge 28 aprile 2010, n. 63' and Andrea Atteritano, 'Il DL 63/2010 compromette il diritto dell'individuo a una effettiva tutela giurisdizionale', (22 September 2010), both available at http://www.sidi-isil.org/? $\mathrm{p}=7965$.

${ }^{75} \mathrm{Cf}$ Benedetto Conforti, 'Il legislatore torna indietro di circa novant'anni: la nuova norma sull'esecuzione sui conti correnti di Stati stranieri', Rivista di diritto internazionale 2 (2015), 558-561. See also: Antonio Chiusolo, 'Immunità giurisdizionale e diritti inviolabili: nuova frontiera per la "giuristocrazia"?', Forum di Quaderni Costituzionali, (14 July 2015), available at http://www.forumcostituzionale.it/wordpress/wp-content/uploads/2015/07/chiusolo-nota-2382014.pdf, at 9-10; Attila Tanzi, 'Sulla sentenza 238/2014: cui prodest?', Forum di Quaderni Costituzionali, (26 November 2014), available at http://www.forumcostituzionale.it/wordpress/ wp-content/uploads/2014/12/nota_238_2014_tanzi.pdf, at 3-4.

${ }^{76}$ ItCC, Judgment 329/1992 (n 63).
} 
enshrined in Article 24 of the Italian Constitution has been infringed because its limitation beyond what customary international law provides is neither sustained by a higher public interest nor proportionate. ${ }^{77}$

As to the second option, the ItCC may also stress the need of providing victims with an effective judicial remedy, since 'the right to a judge enshrined in the Italian Constitution requires an effective protection of the rights of the individual' and cannot be deemed sufficient whenever a private claimant is allowed to file a lawsuit against a foreign state. ${ }^{78}$ The effectiveness of the judicial remedy could be deemed existent only to the extent that an enforcement order can be issued. In doing so, however, the ItCC would overrule its own case-law, which unequivocally distinguished between immunity from adjudication and immunity from execution and thus relying on the case-law of those courts that tend to approximate adjudicatory and enforcement immunity. From this perspective the ItCC would probably have to activate once more the counterlimits so as to preclude customary international law governing immunity from execution to enter the Italian legal order. ${ }^{79}$ Whereas in the first scenario outlined above the ItCC would close the books with Germany but leave totally or partially unsettled the question of reparations, in the second scenario the Corte Costituzionale would coherently follow up Sentenza 238/2014 and tear down the 'last bastion of State immunity'. ${ }^{80}$ The consequences, however, would probably be severe for the bilateral relations between the two states, as Germany might bring a new lawsuit before the ICJ. Such proceedings would constitute an unwelcome development between member states of the EU. An agreed extra-judicial settlement of the already too long-lasting controversy would thus clearly be the best solution. ${ }^{81}$

\footnotetext{
${ }^{77} \mathrm{Cf}$ Fabrizio Marongiu Buonaiuti, 'State Immunity from Enforcement Measures between Respect for State Sovereignty and Access to Justice', in Ermanno Calzolaio/Pierre Serrand (eds), La contrainte en droit-The constraint in Law, (Zurich: LIT Verlag 2017), 167-186, at 181-182. Doubts were raised also by Riccardo Luzzatto/Ilaria Queirolo, 'Sovranità territoriale, "Jurisdiction" e Regole di Immunità', in Sergio M Carbone/Riccardo Luzzatto/Alberto Santa Maria (eds), Istituzioni di diritto internazionale (Turin: Giappichelli $5^{\text {th }}$ ed 2016), 203-241, at 206-207. See also Riccardo Pavoni, chapter 'A Plea for Legal Peace', in this volume.

${ }^{78}$ As pointed out in the case-law of the Italian Constitutional Court, Article 24 of the Italian Constitution protects also the right to enforcement. See, inter alia, Judgments of 11 June 2014, No 182/2014; of 3 June 2013, No 119/2013; of 7 July 2010, No 281/2010, and of 5 March 2007, No $77 / 2007$.

${ }^{79}$ See also Paolo Palchetti, chapter 'Right of Access to (Italian) Courts über alles?', in this volume. ${ }^{80}$ This expression belongs to Special Rapporteur Sompong Sucharitkul. Cf Eighth Report on Jurisdictional Immunities of States and Their Property. See in this respect, ILC, Report on the Work of the thirty-eighth session (1986), UN Doc A/CN.4/396, Draft Article 18 (para 2).

${ }^{81}$ For similar considerations, Karin Oellers-Frahm, 'Suggesting Solutions: What About Concessions to be Made by Both Sides', VerfBlog, (15 May 2017), available at https://verfassungsblog.de/ suggesting-solutions-what-about-concessions-to-be-made-by-both-sides/.
} 


\section{The Compatibility of a Reparation Scheme with the Italian Constitution}

A different attitude could be displayed by the ItCC if negotiations on a possible reparation scheme for the victims excluded by prior reparations were started, a constellation, however, that appears highly unlikely at the present stage. In this respect, it could be useful to answer the question on the extent to which Italian courts should afford immunity from enforcement if negotiations on a possible reparation scheme were started by Italy and Germany and to what extent this solution would be compatible with Article 24 of the Italian Constitution. The same question could be asked if a law decree suspending attachment and/or execution proceedings were passed after the start of negotiations.

The answers to these questions might differ depending on the terms upon which negotiations would be started, as well as on the content of such a reparation scheme. In the first place, one may consider the unusual reparation scheme outlined by the same Tribunal of Florence. As already mentioned (section II), in its Order of 23 March 2015, when resuming proceedings after the decision of the ItCC the judge attempted to combine domestic procedural law and passages of the ICJ Judgment promoting negotiations. ${ }^{82}$ On the basis of a combined reading of internal legal provisions and a recommendatory statement by an international court, the Tribunal of Florence suggested a sui generis conciliation proposal, whose acceptance by all parties to the proceedings was conditional upon both the withdrawal of the claim for reparation by the applicants and the financial compensation amounting to up to $€ 15,000$ by the Federal Republic of Germany specifically for a cultural study visit to Germany for the victim's families. This equitable settlement being reached on an individual basis, albeit not well-founded in positive law, ${ }^{83}$ would have had the merit of allowing the judge to do away with the question of whether immunity from execution ought to be lifted.

A different outcome would probably occur if Italy and Germany willingly decided to conduct negotiations on a compensation fund covering all the remaining victims and not only the plaintiffs of a single or a given number of proceedings. ${ }^{84} \mathrm{In}$ this respect, in entering into negotiations with Germany and upon condition of their successful conclusion, Italy would itself waive the damages claims in the name of its

\footnotetext{
${ }^{82}$ Tribunale di Firenze, Order No 2012/1300 (n 8), referring to ICJ, Jurisdictional Immunities (n 9), paras 99 and 104.

${ }^{83}$ As pointed out by Oellers-Frahm, 'A Never-Ending Story' 2016 (n 8), 198.

${ }^{84}$ As pointed out by Thomas Giegerich, 'Do Damages Claims Arising from Jus Cogens Violations Override State Immunity from the Jurisdiction of Foreign Courts?', in Christian Tomuschat/JeanMarc Thouvenin (eds), The Fundamental Rules of the International Legal Order: Jus Cogens and Obligations Erga Omnes (Leiden/Bosten: Martinus Nijhoff 2006), 203-238, at 221: '[D]iplomatic or other international mechanisms are arguably more appropriate, as allowing civil claims by individual victims would give some individuals large sums of money while the majority of the victims would come away empty-handed'.
} 
citizens, as traditionally occurs under international law. Would this waiver conform to Article 24 of the Italian Constitution?

The ItCC could seize the opportunity to explore whether the international customary rule-according to which claims to reparations arising from violations of the law of armed conflicts can be waived by states in virtue of their sovereigntyinfringes upon Article 24 of the Italian Constitution. Unlike a treaty by means of which two states entirely waive the damages claims of their citizens, the present bilateral arrangement would rather be aimed at providing a symbolic compensation to all victims excluded from prior reparation agreements and not, as such, at defeating the power of the victims to adjudicate upon claims lodged before domestic tribunals. By contrast, it would be difficult to imagine that such an agreement will still allow claims regarding the modalities and to the extent to which reparation by Germany should take place. $^{85}$

Therefore, it would be difficult for the ItCC to state that the right of access to justice as enshrined in Article 24 of the Italian Constitution has been violated: once adjudication on the merits has been allowed, the question as to how and to what extent the victims will receive satisfaction, as long as it will ultimately somehow be ensured, should not concern constitutional judges but rest within the discretion of the state on how to provide them with reparation. ${ }^{86}$

\section{Concluding Remarks}

The above considerations highlight a series of problems resulting from the attempt of a domestic court, rectius a constitutional court, to contribute to the development of international law. There is no question that issues of state immunity might need reconsideration as demonstrated by the adoption of the 2004 UN Convention on Jurisdictional Immunities of States and Their Property. ${ }^{87}$ The fate of this Convention as such is, however, revealing: that ratifications are sparse shows that states are reluctant to accept the rules. ${ }^{88}$ Moreover, the attempt to apply such desirable but not yet generally accepted new rules to situations dating back more than 70 years and resulting from war-related actions raises more problems than it resolves. The possibility of re-assessing war-related acts under currently accepted human rights law raises not only the question of the reasonableness but also the feasibility of such an undertaking.

\footnotetext{
${ }^{85} \mathrm{Cf}$ Chiusolo, 'Immunità giurisdizionale' 2015 (n 75), 23-24.

${ }^{86}$ See also Riccardo Pavoni, chapter 'A Plea for Legal Peace', in this volume. Cf Paolo Palchetti, chapter 'Right of Access to (Italian) Courts über alles?', in this volume.

${ }^{87}$ UN Convention on Jurisdictional Immunities of States and Their Property (2 December 2004), UN Doc A/RES/59/38, UN Doc A/59/49, 486 (not yet in force).

${ }^{88}$ Until November 2020 , there were only 22 ratifications and 28 signatories to the Convention.
} 
However, the activism of national courts relating to new developments in international law should reflect the overall consequences: denying state immunity with regard to jurisdiction only partially resolved the question-and the Corte Costituzionale was undoubtedly aware of this fact. The hope that might have propelled the ItCC towards its decision, that immunity from execution might be denied on the same reasons as jurisdictional immunity, could only be considered as equivocal at that time. To entrust the further development of this issue to national jurisdictions and not to the international community could only result in judicial activism to the detriment of the people concerned: the victims of war crimes and their heirs. To raise their hopes of being awarded reparations only for said reparations to be impossible to realize seems rather cynical indeed, as it disregards the expectations of individuals originating from an ambitious, but short-sighted, decision of the ItCC. As long as Germany is not ready to step back from its legally justified denial of awarding reparations ${ }^{89}$ and Italy maintains its disregard for binding international law, the question will remain open for an unforeseeable future, since Italian judges will continue awarding compensation to the victims that Germany will ultimately not provide.

In this regard, and in order to finally close the chapter of WWII, a possible solution might be found either in the creation of a fund mutually established by Italy and Germany ${ }^{90}$ or by a unilateral action by Germany following the example of the reparations awarded to Russian prisoners of war: ${ }^{91}$ In this instance, the German parliament formally recognized 'responsibility for that part of the terrible events of the Nazi period and World War II' and awarded 'as a symbolic financial recognition for their suffering' the payment of $€ 2,500$ to each of the some 4,000 Russian prisoners still alive. ${ }^{92}$ Jochen Abraham Frowein was right to consider the question of reparations as settled, but also that Germany was free to offer reparations through 'unilateral measures', adding, however, that the situation of Russian prisoners was unique and therefore should not be considered as a precedent to be extended to other cases. ${ }^{93}$ Consequently, there is no legal obligation to award reparations to Italian victims of German war crimes and replicate the solution reached for Russian

\footnotetext{
${ }^{89}$ The German attitude seems in particular understandable with a view to compensations claims from other sides, as eg the compensation recently claimed by Poland. In the opinion delivered by the German Bundestag, Germany confirms its position also with regard to Poland that all war-related claims have been waived; cf Deutscher Bundestag-Wissenschaftliche Dienste, 'Völkerrechtliche Grundlagen und Grenzen kriegsbedingter Reparationen unter besonderer Berücksichtigung der deutsch-polnischen Situation', (28 August 2017), available at www.bundestag.de/blob/525616/ 211fd144be8368672e98ecd6a834fe25/wd-2-071-17-pdf-data.pdf.

${ }^{90}$ See also Stefan Kadelbach, chapter 'State Immunity, Individual Compensation for Victims of Human Rights Crimes, and Future Prospects', and Francesco Francioni, chapter 'Overcoming the Judicial Conundrum', in this volume.

${ }^{91} \mathrm{Cf}$ section III.3 and $\mathrm{n} 34$.

${ }^{92} \mathrm{Cf}$ Deutscher Bundestag, 'Plädoyer für Entschädigungen', (19 May 2015), available at www. bundestag.de/presse/hib/2015_05/-/375140 (translated by the authors).

${ }^{93}$ Ibid.
} 
prisoners of war. But Germany remains free to act on a unilateral basis, in particular wherever victims exist who have hitherto been excluded from any reparation scheme, so as to finally close the dispute troubling the otherwise friendly relations between Italy and Germany.

\section{References}

Atteritano, Andrea, 'Il DL 63/2010 compromette il diritto dell'individuo a una effettiva tutela giurisdizionale', (22 September 2010), available at http://www.sidi-isil.org/wp-content/uploads/ 2010/02/Atteritano-DL-Immunit\%C3\%A0-definitivo1.pdf

Baiada, Luca, 'Ancora sull'esecuzione su beni di Stato estero', Questione Giustizia, 30 September 2019.

Bank, Roland/Elke Schwager, 'Is There a Substantive Right to Compensation for Individual Victims of Armed Conflict against a State under International Law', German Yearbook of International Law 49 (2006), 367-411

Berrino, Giorgia, 'La Corte di Cassazione torna sul tema delle immunità giurisdizionali degli Stati stranieri e dei loro beni', Rivista di diritto internazionale 3 (2020), 844-858

Boggero, Giovanni, 'Ancora sul seguito della sentenza n. 238/2014: una recente pronuncia del Tribunale di Sulmona', (20 November 2017), available at www.diritticomparati.it/ancora-sulseguito-della-sentenza-n-2382014-una-recente-pronuncia-del-tribunale-di-sulmona/

Boggero, Giovanni, 'The Legal Implications of Sentenza No. 238/2014 by Italy's Constitutional Court for Italian Municipal Judges: Is Overcoming the 'Triepelian Approach' Possible?', Heidelberg Journal of International Law 76 (2016), 203-224

Brown, Chester/Roger O'Keefe, 'Part IV State Immunity from Measures of Constraint in Connection with Proceedings Before a Court, Preliminary Material', in Roger O'Keefe et al (eds), The United Nations Convention on Jurisdictional Immunities of States and Their Property (Oxford: OUP 2013), 288-293

Bufalini, Alessandro, 'La riparazione per gravi violazioni dei diritti umani e del diritto umanitario tra rinuncia dello stato e diritto individuale', in Andrea Spagnolo/Stefano Saluzzo (eds), $\mathrm{La}$ responsabilità degli stati e delle organizzazioni internazionali (Milan: Ledizioni 2017), 375-391

Cannizzaro, Enzo, 'Is There an Individual Right to Compensation?', in Denis Alland et al (eds), Unité et diversité du droit international (Leiden: Brill Nijhoff 2014), 495-502

Cataldi, Giuseppe, 'Immunités juridictionnelles des Etats étrangers et droit de l'homme: quel équilibre entre les valeurs fondamentales de l'ordre national et le droit international coutumier?', in James Crawford et al (eds), The International Legal Order: Current Needs and Possible Responses (Leiden: Brill Nijhoff 2017), 571-590

Cataldi, Giuseppe, 'La Corte costituzionale e il ricorso ai "contro-limiti" nel rapporto tra consuetudini internazionali e diritti fondamentali', Diritti umani e diritto internazionale 9 (2015), 41-50

Chiusolo, Antonio, 'Immunità giurisdizionale e diritti inviolabili: nuova frontiera per la “giuristocrazia"?', Forum di Quaderni Costituzionali, (14 July 2015), available at http://www. forumcostituzionale.it/wordpress/wp-content/uploads/2015/07/chiusolo-nota-238-2014.pdf

Comoglio, Luigi Paolo, 'Principi costituzionali e processo di esecuzione', Rivista di diritto processuale 2 (1994), 450-469

Conforti, Benedetto, 'Il legislatore torna indietro di circa novant'anni: la nuova norma sull'esecuzione sui conti correnti di Stati stranieri', Rivista di diritto internazionale 2 (2015), $558-561$ 
De Santis, Barbara, 'Profili di giurisdizione nell'esecuzione forzata sui beni dello Stato estero', Judicium-Il processo civile in Italia e in Europa, 30 April 2020

Focarelli, Carlo, 'Diniego dell'immunità giurisdizionale degli Stati stranieri per crimini, jus cogens e dinamica del diritto internazionale', Rivista di diritto internazionale 91 (2008), 738-757

Fox, Hazel/Philippa Webb, The Law of State Immunity (Oxford: OUP $3^{\text {rd }}$ ed 2013)

Frulli, Micaela, "The Times they are A-Changing"- the Italian Court of Cassation Denies Germany Immunity from Execution to Allow Compensation to War Crimes' Victims', Journal of International Criminal Justice 9 (2011), 1129-1142

Gattini, Andrea, Le riparazioni di guerra nel diritto internazionale (Padua: CEDAM 2003)

Gattini, Andrea, 'The Dispute on Jurisdictional Immunities of the State before the ICJ: Is the Time Ripe for a Change in the Law?', Leiden Journal of International Law 24 (2011), 173-200

Giegerich, Thomas, 'Do Damages Claims Arising from Jus Cogens Violations Override State Immunity from the Jurisdiction of Foreign Courts?', in Christian Tomuschat/Jean-Marc Thouvenin (eds), The Fundamental Rules of the International Legal Order: Jus Cogens and Obligations Erga Omnes (Leiden/Bosten: Martinus Nijhoff 2006), 203-238

Hess, Burkhard, 'Kriegsentschädigungen aus kollisionsrechtlicher und rechtsvergleichender Sicht', in Wolff Heintschel von Heinegg (ed), Entschädigung nach bewaffneten Konflikten: die Konstitutionalisierung der Welthandelsordnung (Heidelberg: Müller 2003), 107-205

Higgins, Rosalyn, 'Some Observations on the Inter-Temporal Rule in International Law', in Jerzy Makarczyk (ed), Theory of International Law at the Threshold of the 21st Century (The Hague: Kluwer 1996), 173-181

Kloth, Matthias, Immunities and the Right of Access to Court under Article 6 ECHR, (Leiden/ Boston: Martinus Nijhoff 2010)

Linden, Mieke van der, 'The Inextricable Connection between Historical Consciousness and International Law', Select Proceedings of the ESIL 5 (2014), 447-460

Longobardo, Marco, 'The Italian Constitutional Court's Ruling Against State Immunity When International Crimes Occur: Thoughts on Decision No. 238 of 2014', Melbourne Journal of International Law 16 (2015), 255-269

Lopes Pegna, Olivia, 'Giù le mani da Villa Vigoni: quale tutela "effettiva" per le vittime di gravi crimini compiuti da Stati esteri?', Rivista di diritto internazionale 4 (2018), 1237-1244

Luzzatto, Riccardo/Ilaria Queirolo, 'Sovranità territoriale, "Jurisdiction" e Regole di Immunità', in Sergio M Carbone/Riccardo Luzzatto/Alberto Santa Maria (eds), Istituzioni di diritto internazionale (Turin: Giappichelli $5^{\text {th }}$ ed 2016), 203-241

Mariottini, Cristina M, 'Case Note: Deutsche Bahn AG v. Regione Stereá Ellada', American Journal of International Law 3 (2020), 486-493

Marongiu Buonaiuti, Fabrizio, 'State Immunity from Enforcement Measures between Respect for State Sovereignty and Access to Justice', in Ermanno Calzolaio/Pierre Serrand (eds), $\mathrm{La}$ contrainte en droit-The constraint in Law (Zurich: LIT Verlag 2017), 167-186

Marxsen, Christian, 'What do Different Theories of Customary International Law Have to Say about the Individual Right to Reparation under International Humanitarian Law', Heidelberg Journal of International Law 78 (2018), 581-586

Oellers-Frahm, Karin, 'A Never-Ending Story: The International Court of Justice-The Italian Constitutional Court-Italian Tribunals and the Question of Immunity', Heidelberg Journal of International Law 76 (2016), 193-202

Oellers-Frahm, Karin, 'A Regional Perspective on the Convergence and Conflicts of Human Rights and International Humanitarian Law in Military Operations: The European Court of Human Rights', in Erika de Wet/Jann Kleffner (eds), Convergence and Conflicts of Human Rights and International Humanitarian Law in Military Operations (Pretoria: Pretoria University Law Press 2014), 333-363 
Oellers-Frahm, Karin, 'Das italienische Verfassungsgericht und das Völkerrecht-eine unerfreuliche Beziehung, Anmerkung zur Entscheidung des italienischen Verfassungsgerichts vom 22. Oktober 2014', Europäische Grundrechte-Zeitschrift 42 (2015), 8-16

Oellers-Frahm, Karin, 'Judicial Redress of War-Related Claims by Individuals: The Example of the Italian Courts', in Ulrich Fastenrath et al (eds), From Bilateralism to Community Interest: Essays in Honour of Judge Bruno Simma (Oxford: OUP 2011), 1055-1078

Oellers-Frahm, Karin, 'Suggesting Solutions: What About Concessions to be Made by Both Sides', VerfBlog, (15 May 2017), available at https://verfassungsblog.de/suggesting-solutions-whatabout-concessions-to-be-made-by-both-sides/

Orakhelashvili, Alexander, 'State Immunity and International Public Order Revisited', German Yearbook of International Law 49 (2006), 327-365

Palchetti, Paolo, 'Italian Concerns after Sentenza 238/2014: Possible Reactions, Possible Solutions', VerfBlog, (11 May 2017), available at http://verfassungsblog.de/italian-concerns-aftersentenza-2382014-possible-reactions-possible-solutions/

Papa, Maria Irene/Monica Zanobetti, 'Eccidio di Roccaraso: giurisdizione italiana e immunità degli Stati dalla giurisdizione civile', in Il Corriere giuridico 6 (2018), 788-798

Pavoni, Riccardo, 'How Broad is the Principle Upheld by the Italian Constitutional Court in Judgment No. 238?', Journal of International Criminal Justice 14 (2016), 573-585

Raffeiner, Stefan, 'Jenseits der Staatenimmunität im deutsch-italienischen StaatenimmunitätenFall: Wege und Hürden nach dem Urteil der Corte Costituzionale', Heidelberg Journal of International Law 76 (2016), 451-473

Reinisch, August, 'European Court Practice Concerning State Immunity from Enforcement Measures', The European Journal of International Law 17 (2006), 803-836

Rossi, Pierfrancesco, 'The Aftermath of the Italian Constitutional Court Judgment No. 238 of 2014 in Exequatur and Enforcement Proceedings', Italian Yearbook of International Law 28 (2018), 455-459

Salerno, Francesco, 'Esecuzione in Italia su beni di Stati stranieri: il decreto-legge 28 aprile 2010, n. 63', (22 September 2010), available at http://www.sidi-isil.org/wp-content/uploads/2010/02/ Salerno-Decreto-legge-28-aprile-2010-_1_.pdf

Tanzi, Attila, 'Sulla sentenza 238/2014: cui prodest?', Forum di Quaderni Costituzionali, (26 November 2014), available at http://www.forumcostituzionale.it/wordpress/wp-content/ uploads/2014/12/nota_238_2014_tanzi.pdf

Thouvenin, Jean-Marc/Victor Grandaubert, 'The Material Scope of Immunity from Execution', in Tom Ruys et al (eds), The Cambridge Handbook of Immunities and International Law (Cambridge: CUP 2019), 245-265

Tomuschat, Christian, 'Individual Reparation Claims in Instances of Grave Human Rights Violations: The Position under General International Law', in Albrecht Randelzhofer/Christian Tomuschat (eds), State Responsibility and the Individuals (The Hague: Martinus Nijhoff 1999), 1-25

Werle, Gerhard /Florian Jeßberger, Principles of International Criminal Law (Oxford: OUP $3^{\text {rd }}$ ed 2014)

Wood, Michael, 'Immunity from Jurisdiction and Immunity from Measures of Constraint', in Roger O'Keefe et al (eds), The United Nations Convention on Jurisdictional Immunities of States and Their Property (Oxford: OUP 2013), 13-18

Yang, Xiaodang, 'Immunity from Execution', in Alexander Orakhelashvili (ed), Research Handbook on Jurisdiction and Immunities in International Law (Cheltenham: Edward Elgar 2016), $372-422$ 
Open Access This chapter is licensed under the terms of the Creative Commons Attribution 4.0 International License (http://creativecommons.org/licenses/by/4.0/), which permits use, sharing, adaptation, distribution and reproduction in any medium or format, as long as you give appropriate credit to the original author(s) and the source, provide a link to the Creative Commons license and indicate if changes were made.

The images or other third party material in this chapter are included in the chapter's Creative Commons license, unless indicated otherwise in a credit line to the material. If material is not included in the chapter's Creative Commons license and your intended use is not permitted by statutory regulation or exceeds the permitted use, you will need to obtain permission directly from the copyright holder. 